\title{
1 Technologies for increasing carbon storage in soil to mitigate climate change
}

2 AP Whitmore ${ }^{1}$, GJD Kirk ${ }^{2}$ and BG Rawlins ${ }^{3}$

3

4

5

6

${ }^{1}$ Rothamsted Research, Harpenden, Hertfordshire. AL5 2JQ

${ }^{2}$ Cranfield University, Cranfield, Bedford MK43 OAL

${ }^{3}$ British Geological Survey, Keyworth, Nottingham, NG12 5GG

\section{Abstract}

Means to enhance storage of carbon in soil or avoid its loss from soil are discussed and examined from the viewpoint of policy. In particular, technologies that have until now received little attention are assessed. The main means by which soil carbon might be increased are first listed. These are: (i) increasing the rate of input of organic matter; (ii) decreasing the rate of its decomposition by biological or chemical means; (iii) increasing the rate of its stabilisation by physico-chemical protection within aggregates and organo-mineral complexes; and (iv) increasing the depth or more correctly the total soil volume sequestering carbon at maximum rate.

Immediate gains in carbon storage might be made by switching to more perennial crops, especially grasses that as a result of breeding put more carbon into soil. In the longer term, targets for research such as understanding the role of enzymes in carbon turnover and the exploitation of the capacity in subsoils are suggested. Increased fixation of $\mathrm{CO}_{2}$ as inorganic carbonate in soils by application of silicate wastes may have some role.

\section{Introduction}

The UK Department for Environment, Food and Rural Affairs (Defra) sets soils policy for the England and Wales and since the Millennium Assessment (2001), has adopted an Ecosystem Services approach which is exemplified by the UK National Ecosystem Assessment (Anon, 2011) and has fed into policy through the Natural Environment White Paper (Anon, 2011). Safeguarding Our Soils, A Strategy for England (Defra, 2009) stresses the role that storage of carbon in soil can play in helping to combat climate change and meeting the UK Government's emission reduction targets and carbon budgets in England, introduced by the Climate Change Act 2008. Of particular importance is the ability of soils to regulate carbon in the environment through storage or other means in the soil and the wider value of soil organic carbon (SOC) on soil quality and the role it plays in the provision of habitat for biodiversity. Safeguarding our soils also points out, however, the need that policy-makers have for a robust evidence base with which to inform policy. Although there have been several recent reviews of existing science and methodologies for increasing levels of carbon in soil, here we 
consider less tried and tested technologies for their potential to retain carbon that would otherwise increase atmospheric $\mathrm{CO}_{2}$. Despite the use of UK data, many of the conclusions reached here are relevant to policy-makers world-wide who are grappling with issues surrounding soil carbon and most issues discussed are relevant to policy-makers in NW Europe.

There are two major components to the global carbon cycle: (i) a geological cycle which acts over epochs but cycles very large amounts of carbon because of the time and spatial scales involved, and (ii) a biological cycle that operates over much shorter periods of time. Humanity's current problems and confusion with carbon stem from exploitation of the geological carbon and attempts to fix this by manipulating the biological cycle. Because the two operate at different timescales there are huge amounts of carbon to exploit from geological reserves but little capacity to fix this within the biology. Nevertheless, the biological cycle does have some capacity and it is also worth noting that the two cycles are not entirely distinct: the soil carbon cycle and chemical cycles sit somewhat in between since soil $C$ is derived from the annual biological cycling of plants on the one hand but is capable of long-term physico-chemical preservation in soil for thousands of years in some instances.

Although there is some interest in means to stimulate the uptake of inorganic carbon dioxide directly from the atmosphere, most carbon enters the soil through the plant

In this review we consider some novel ways in which policy might be used to steer interventions in these short-term natural cycles in order to weigh the balance in favour of increased net input or storage of carbon in soil. The principal factors that determine $C$ sequestration in the soil are:

1. the rate of input of organic matter;

2. the rate of its decomposition by biological or chemical means;

3. the rate of its stabilisation by physico-chemical protection within aggregates and organomineral complexes; and

4. the depth or more correctly the total soil volume sequestering carbon at maximum rate.

In this analysis a distinction has been made between physical methods of reducing decomposition (3) of organic matter which tend to halt turnover, and methods which act on the chemical and biological processes (2) because these latter tend to slow decomposition down rather than stop it altogether. For previous reviews of this topic see Smith et al. (2000), Powlson et al. (2011) and Stockmann et al. (2013).

\section{Increasing the rate of input of organic matter to soils}

\section{Agroforestry and intercropping}

Forest and woodland ecosystems contain more carbon than pasture or arable (Bolin et al., 2000). Although levels of soil carbon in the soils of the most productive pastoral systems can approach the 
levels found in forest soils (Bolin et al., 2000), arable soils usually contain much less $C$ than either forest or pasture (Bolin et al., 2000). Mixed systems, that is to say trees and arable (known as silvoarable or agroforestry systems) or trees and grass (known as silvopastoral systems) have been proposed as a means to extend the benefits of forest to farmed land. Because different species use resources differently, they can be complementary with one another, often yielding more and consuming less than corresponding sole crops. It has been suggested recently that agroforestry and intercropped systems increase the store of carbon in land managed for production (Nair et al., $2009 a, b)$. Nair et al (2009b) report a range of soil C sequestration data with modest values of around $1 \mathrm{Mg} \mathrm{C}^{-1}$. Gupta et al. (2009) found $3 \mathrm{Mg}$ increase in one year and a $6 \mathrm{Mg} \mathrm{ha}^{-1}$ increase during six years, with little difference in loamy sand and sandy clay soils. Agroforestry and silvopastoral systems contain more carbon in soil than cropland, but almost all the evidence comes from work in tropical and sub-tropical soils with little work in temperate systems (Jose, 2009). Even in these studies, few woodland controls exist so it is not clear if the resource-use complementarity referred to above leads to extra carbon storage relative to sole species. Quinkenstein et al., 2009; and Montagnini \& Nair (2004) who reviewed C sequestration in soils under temperate agroforestry systems cite a figure of 63-76 Mg C ha-1 but the source of these values is unclear. There is a need to assess the potential of temperate agroforestry systems for increasing soil C

Mixed tree and crop systems will stimulate the nitrogen cycle as well as the carbon cycle and a $25 \%$ increase in emissions of $\mathrm{N}_{2} \mathrm{O}$ has been found on a loamy soil in China (e.g. Guo et al., 2009). Verchot et al. (2008), however, found no increase in $\mathrm{N}_{2} \mathrm{O}$ emitted on a sandy soil in the Amazon, nor was $\mathrm{CH}_{4}$ oxidation capacity of the soil affected. Results from the UK are lacking. If intercropped systems are to be widely adopted in the UK, for whatever reason, the potential for increased $\mathrm{N}_{2} \mathrm{O}$ emissions needs to be assessed. Leaching of dissolved organic carbon (DOC) can often be high in forest systems (e.g. Kalbitz et al., 2004), but there is no evidence to show a change in DOC production and loss in agroforestry or silvopastoral systems.

Intercropping field crops might improve $\mathrm{C}$ storage relative to monoculture controls too. Bolin et al. (2000) quote data suggesting that temperate grasslands store $236 \mathrm{C} \mathrm{Mg} \mathrm{ha}^{-1}$ as a global average. Sequestration rates of $65-70 \mathrm{Mg} \mathrm{ha}^{-1}$ in 100 years have been quoted (Abberton et al., 2007). On the other hand Skinner et al., (2006) found that soil C either remained the same with species mixtures or declined during two years after sowing into a soil that had previously supported winter wheat. The potential for soil carbon storage in intercropped soils does not appear to have been widely investigated.

\section{Perennial in place of annual crops}

The development of perennial crops in place of current annual ones such as wheat through plant breeding may lead to gains in soil C (Royal Society, 2009a). In general, perennial plants store more C than annuals as the annual cycle of cultivation does little to maintain storage. Perennial crops are in 
the ground all year long and intercept more of the sun's radiation as a result (e.g. Glover et al., 2010). It follows that a change from arable to perennial grassland is likely to lead to a significant increase in soil C (Guo \& Gifford, 2002). By implication therefore, a change from annual to perennial grain crops should also lead to an increase in SOC. Because they live longer, many perennials invest in deep, extensive root systems which are efficient in scavenging for nutrients and water as well as putting carbon in to soil. The amount of $C$ retained by soils is influenced greatly by management practices, with those that lead to reduced soil disturbance and for increased crop persistency having the greatest benefits on $\mathrm{C}$ sequestration. Moreover, perennial vegetation may receive fewer passes with machinery, so consuming less energy because perennial systems are more diverse and receive fewer sprays that consume fossil fuels in their manufacture. However to date there are no perennial crop species that produce adequate grain yields. The Royal Society (2009a) estimates that it will be at least 10 years before the development of commercial varieties.

\section{Improved grasses}

The key plant traits likely to influence $\mathrm{C}$ sequestration (root depth, structure and architecture; litter composition and amount) are reasonably well established and genetic variation is beginning to be characterized for many of them. Some early progress has been made with regard to mapping of genes in perennial ryegrass for $C$ sequestration, with effective $C$ return in litter (Abberton et al., 2007). Key questions to be resolved are the extent to which investment of photosynthate below ground is at the expense of above-ground productivity, and how much of the additional below-ground carbon can be stored in subsoils for the long term.

\section{Roots, exudation and priming effects}

Although roots obviously put carbon directly belowground, root turnover can be appreciable and the roots of many plants exude large amounts of carbon-containing polymeric compounds into soil over the course of a growing season. Grazing enhances rhizodeposition thus temporarily changing the balance between root and shoot production (Hamillton III et al, 2008). Plants are themselves also subject to grazing by animals whose droppings or carcases (in the case of wild animals) usually return carbon to soil eventually. Grazing can occur both above and below-ground since many insects have a larval stage in the soil. Clearly, total input to soil depends on the balance between the reduction in photosysnthesis due to grazing and the temporary diversion of carbon into soil.

Plants send varying amounts of carbon belowground and a large part of the belowground $\mathrm{C}$ is exuded from roots into the rhizosphere. Jones et al. (2009) estimate net rhizodeposition at around $11 \%$ of the net fixed C or $27 \%$ of $C$ allocated to roots. This would correspond to $400-600 \mathrm{~kg} \mathrm{C}^{-1}$ during the vegetative period of grasses and cereals. However below-ground $\mathrm{C}$ allocation and exudation vary between and within plant species, and with light conditions, soil moisture and nutrient conditions, grazing and other variables. Soil microbes and fungi also release carbon compounds into the 
environment. While bacteria are relatively well studied, far less is known about soil fungi (de Boer, 2005). In the vast majority of cases, however, the ultimate source of the carbon that is processed and exuded by the soil microbes is derived originally from plants and photosynthesis.

Some authors suggest that inputs of fresh plant-derived carbon and other root-induced changes in the soil increase the turnover of existing Soil Organic Matter (SOM, Paterson et al., 2009; Kuzyakov, 2010). Such 'priming' effects are not well understood, and they are not allowed for in most current models (Wutzler \& Reichstein, 2008; Blagodatsky et al., 2010). However, artefacts may account for many of these observations. Fontaine et al. (2007) working with ex situ cores found turnover of old SOM in subsoil was stimulated by addition of fresh organic matter but Salome et al (2009), who carefully reproduced subsoil conditions, found no priming in soils from below $30 \mathrm{~cm}$. While it is possible that some observed instances of priming are the result of artefacts there is nonetheless considerable interest in this area (Stockmann et al., 2013)

\section{Decreasing the rate of decomposition of organic matter in soils}

In this section we review recent advances in the understanding of certain biological and chemical controls on the rate of decomposition of organic matter (OM) in soils, largely drawn from observation in the natural environment. In this respect the research is at a preliminary stage, so it is not yet possible to draw conclusions about practical soil management interventions based on it.

\section{SOC turnover}

Studies of decomposition of organic matter in peatlands have shown inhibition of the enzymes responsible by phenolic compounds (Freeman et al., 2001; Zibilske \& Bradford, 2006; Toberman et al., 2008; Sinsabaugh, 2010; Benoit \& Starkey 1968a,b). These studies point to a particular role of phenolic compounds in the carbon cycle with three key features: (i) few enzymes degrade these abundant materials and those enzymes that do are inhibited almost completely by certain conditions or a combination of conditions found in peat; (ii) phenolic compounds inhibit other enzymes, particularly those that decompose organic matter in soil; and (iii) many phenolic compounds bind other OM especially proteins and enzymes, this in itself has two further effects: (a) it reduces the availability of OM for decomposition and (b) it removes other enzymes such as hydrolases that effect that decomposition.

The surprising conclusion from this review of research is that a key oxidation step in the decomposition of organic matter in soil is susceptible to inhibition by a specific class of phenolic compounds. Carbon accumulation in peat soils may be the result of restricted oxidase and peroxidise activity that remove these phenols, which in turn is the result of a lack of oxygen but does not result from any general impact of the lack of oxygen on the soil microflora as a whole. If so, organic matter decomposition in soil might be reduced by the application of inhibitors or anti-oxidants. 
Aerts et al. (1999) have exploited the ability of phenol-containing substances to bind proteins by ensuring their presence in the rumen of sheep by adding polyphenol-containing (tannin) forage residues to the animals' diet. Aerts et al. (1999) attribute the beneficial effects on the animals to the ability of the tannins to bind both proteins in the feed and the enzymes responsible for degradation under the anaerobic conditions in the rumen. Proteins, especially then survive long enough to reach other parts of the animals' guts where they can be absorbed, so improving the effectiveness of the nutrition. Intriguingly, this raises the possibility that tannin-rich diets might lead to the introduction of tannins to soil via manure and so reduce the turnover of organic carbon in soil.

In separate work, Rimmer (2006) proposed the more general hypothesis that the decomposition of plant residues in soil is effected by free radicals and that anti-oxidants such as quinines which are common in soil, moderate this activity by quenching the free radicals. Thus, observed SOC turnover would be the balance between these components. Phenols and polyphenols are anti-oxidants. Rimmer \& Smith (2009) have found anti-oxidants in soil and have related the anti-oxidant capacity of soils to the total soil carbon content but did not find evidence that the anti-oxidant capacity of the soil was derived from plant litter. Additionally they found that anti-oxidant capacity decreased with depth in the soil (Rimmer \& Smith, 2009). There has been little further uptake of these ideas in the scientific literature and the key experiments where anti-oxidants are deliberately introduced into soil or removed appear to be lacking. Organic amendments naturally containing large amounts of anti-oxidants were found to decompose more slowly during an initial 7 day period than amendments without anti-oxidants

191 (Rimmer et al., 2013)

Biochar - the porous carbonaceous solid produced by thermochemical conversion of organic materials in an oxygen depleted atmosphere has been reviewed recently by Shackley \& Sohi (2009) and will not be repeated here. Essentially these authors conclude the residence time of biochar in soil is often in the order of millennia as opposed to a few tens of years for other soil organic carbon. They review benefits to yield and possible mechanisms for this but also the risks associated with adding biochar to soil. These include a liming benefit but also the potential addition of long-lived toxins along with the char.

\section{Wetlands}

Grip (drain) blocking in peat soils is hypothesised to reduce carbon losses through reduced decomposition and reduced loss of dissolved organic carbon. Billett et al. (2010) suggest that current rates of accumulation of carbon in UK peatlands (56 to $72 \mathrm{~g} \mathrm{C} \mathrm{m}^{-2} \mathrm{yr}^{-1}$ ) are at the low end of rates seen during the last 150 years. However, losses of methane may increase and the tradeoff between reduced emssions of $\mathrm{CO}_{2}$ and adverse effects of emission of $\mathrm{CH}_{4}$ are currently being assessed for the UK (Defra, 2012). Consequently, it is too early to assess restoration of upland peat as a 
technology for reducing overall Green House Gas (GHG) emissions even if it is highly likely to increase stores of carbon.

Managed realignment of coastal defences is also a possible means to increase carbon storage if the deposited sediments contain carbon eroded with soil. Here it appears that a balance must be struck with the emission of $\mathrm{N}_{2} \mathrm{O}$ from denitrification and that the ideal is the establishment of saline rather than non-saline marshes (Andrews et al., 2006)

Powlson et al. $(2011,2012)$ have reviewed the scope for increasing soil carbon by reducing tillage and adding organic materials to soil. In general this work agreed with earlier studies as to the quantities of carbon involved but differed somewhat in interpretation. Direct drilling probably allows soil to increase in SOC by about $0.3 \mathrm{t} \mathrm{ha}^{-1} \mathrm{yr}^{-1}$ although the data available for UK conditions is not sufficient to say if this figure is statistically greater than zero. Most soils in the UK that are not ploughed are in some kind of rotational tillage. Here the risk is that even if there is a gain in carbon stored during the non-inversion rotation, on ploughing this gain will be lost (Conant et al., 2007). Powlson et al. $(2011,2012)$ also consider the addition of organic waste materials to soil such as manure or straw. Here the result is less equivocal as regards a change in soil organic carbon status but with regard to climate change Powlson et al. (2011) also caution that the original use of a material must be considered before its addition to soil can be considered as carbon sequestration in the service of mitigation of climate change. If the material is simply diverted from one soil to another then this can hardly be interpreted as genuine sequestration

\section{Enhanced mineral weathering in soils to sequester $\mathrm{CO}_{2}$}

One of the methods proposed to 'geo-engineer' the global climate is to accelerate the weathering of silicate rocks on land to form carbonate rocks, thereby fixing $\mathrm{CO}_{2}$ from the atmosphere (Royal Society, 2009b). Conversion of silicates to carbonates is the main natural control on atmospheric $\mathrm{CO}_{2}$ on Earth on geological timescales. The proposal is to accelerate it by applying finely-divided silicate rocks (e.g. olivine) to soils, with the carbonate so fixed being stored in the soil as mineral carbonate and, ultimately, exported in drainage waters to rivers and the deep ocean. The ecological consequences of this for the land surface and seas are highly uncertain. In addition, the potential for this method and its immediate consequences for soils are unknown.

The literature on this at the planetary or national scale is thin (Schuiling \& Krijgsman, 2006; Hartmann \& Kempe, 2008). However there is plenty of information on rates of mineral weathering in soils (e.g. Moulton et al., 2000; Andrews \& Schlesinger, 2001; and references therein) and the fate of lime (e.g. Kirk et al., 2010 and references therein). The conclusions from this literature review are as follows. 
242 The removal of $\mathrm{CO}_{2}$ from the atmosphere by precipitation as mineral carbonates (either $\mathrm{Ca}$ or $\mathrm{Mg}$ or

243 both) can be summarised with the reaction

$\mathrm{Ca}^{2+}+\mathrm{CO}_{2}+2 \mathrm{OH}^{-}=\mathrm{CaCO}_{3}+\mathrm{H}_{2} \mathrm{O}$

i.e. the reaction requires sources of $(a)$

(a) $\mathrm{CO}_{2}$, (b)

(b) $\mathrm{Ca}^{2+}$ or $\mathrm{Mg}^{2+}$ cations and

(c) base, i.e. Brønsted base, capable of neutralizing $\mathrm{H}^{+}$ions. Soils are a good source of $\mathrm{CO}_{2}$ for this purpose because $\mathrm{CO}_{2}$ fixed from the atmosphere by plants is released into the soil through the decomposition of plant exudates and residues. As a result the $\mathrm{CO}_{2}$ pressure in the soil air is typically five to 50 times that in the bulk atmosphere.

The planetary-scale carbon sequestration sought by geo-engineers requires silicate applications in excess of acidifying processes so that the base in the silicates is transformed to carbonates on land or ultimately in the deep ocean. Precipitation of carbonates in the soil as a result of large additions of silicate base might occur, depending on rates of carbonate precipitation versus rates of $\mathrm{HCO}_{3}{ }^{-}$ leaching. But large-scale carbonate precipitation in soils is probably not desirable given its likely effects on soil conditions and plant growth. So the aim would be to generate increases in the flux of $\mathrm{HCO}_{3}$ - through soils, rivers and into the sea. If the carbonate remains dissolved in the sea, rather than precipitating, then two moles of $\mathrm{CO}_{2}$ are stored per mol of $\mathrm{Ca}$ silicate weathered, or four moles of $\mathrm{CO}_{2}$ in the case of $\mathrm{Mg}$ silicates.

Transfer of carbonate out of the soil requires that the soil $\mathrm{pH}$ be raised to the point where leaching of the bicarbonate anion $\mathrm{HCO}_{3}{ }^{-}$with metal cations $\mathrm{M}^{+}$is significant. Typically this means $\mathrm{pHs}$ greater than neutral. Similar reasoning explains the well-known phenomenon that the neutralizing effect of lime applied to the soil surface is only transferred to the subsoil when there is an excess of $\mathrm{CaCO}_{3}$ in the surface. Russell (1973) reports that soils containing free $\mathrm{CaCO}_{3}$ in temperate regions may lose $\mathrm{Ca}^{2+}$ with $\mathrm{HCO}_{3}$ - in leachate at rates of the of order of $2.5 \mathrm{~kg} \mathrm{CaCO}_{3} \mathrm{ha}^{-1} \mathrm{y}^{-1}$, based on measurements in lysimeters. Calcareous soils at Rothamsted lose $300-400 \mathrm{~kg} \mathrm{CaCO}_{3} \mathrm{ha}^{-1} \mathrm{y}^{-1}$. Soils without free $\mathrm{CaCO}_{3}$ will also leach $\mathrm{Ca}^{2+}+\mathrm{HCO}_{3}$. But the lower the $\mathrm{pH}$ and the less the saturation of the soil exchange complex with $\mathrm{Ca}^{2+}$, the lower will be the loss. In arable land with heavy dressings of ammoniacal fertilizers, loss of $\mathrm{Ca}^{2+}$ with $\mathrm{NO}_{3}{ }^{-}$will be much greater than its loss with $\mathrm{HCO}_{3}{ }^{-}$.

A further issue is how to maximise the rate of dissolution of silicates, favoured by low $\mathrm{pH}$, whilst maximising the leaching of $\mathrm{M}^{+}+\mathrm{HCO}_{3}^{-}$, favoured by high $\mathrm{pH}$. Manning and Renforth (2013) give data on the thermodynamics of dissolution of the most widely distributed $\mathrm{Ca}$ and $\mathrm{Mg}$ silicates in acid and neutral solutions, and conclude that rates of dissolution will in general be far slower than rates of $\mathrm{CO}_{2}$ generation in plant and soil organic matter turnover. Based on the activation energies given by Manning and Renforth (50-80 kJ mol-1), rates of dissolution are likely to be limited by surface processes rather than by diffusion away from the dissolving surface (for which activation energies are typically in the range $15-30 \mathrm{~kJ} \mathrm{~mol}^{-1}-$ Glasstone et al., 1941). On the same basis, calcite $\left(\mathrm{CaCO}_{3}\right)$ 
277 dissolution is much faster, and likely to be limited by diffusion and the degree of saturation of the soil

278 solution (Nye \& Ameloko, 1987).

279 Also unknown are the ecological consequences of large silicate applications at the site of application.

280 Of concern are the consequences for (a) plant growth, e.g. via deficiencies of $\mathrm{P}$ and micronutrients at 281 high pH in calcifuge plants; (b) soil structure and sealing of the soil by $\mathrm{SiO}_{2}$ precipitation; and (c) the 282 turnover of soil organic matter and leaching of dissolved organic carbon. Equally we know little about 283 the consequences of increased $\mathrm{HCO}_{3}{ }^{-}$fluxes downstream in rivers, local seas, and the deep ocean.

Replacement of agricultural lime with silicates

In theory, there is a significant potential for avoiding carbon emissions by replacing current agricultural lime applications with ground silicates, assuming the $C$ costs of production and transport are the same.

Liming to balance acidity produced in nitrogen transformations, crop off-take, acid deposition etc. releases $1 \mathrm{~mol}$ of $\mathrm{CO}_{2}$ to the atmosphere per $2 \mathrm{~mol}$ of acid (i.e. $\mathrm{H}^{+}$) neutralised.

$\mathrm{CaCO}_{3}+2 \mathrm{H}^{+}=\mathrm{Ca}^{2+}+\mathrm{CO}_{2}+\mathrm{H}_{2} \mathrm{O}$.

Whereas, with silicates there would be no $\mathrm{CO}_{2}$ release, e.g. for the simple olivine $\mathrm{Mg}_{2} \mathrm{SiO}_{4}$ :

$\mathrm{Mg}_{2} \mathrm{SiO}_{4}+4 \mathrm{H}^{+}=2 \mathrm{Mg}^{2+}+\mathrm{H}_{4} \mathrm{SiO}_{4}$

According to Defra (2008), average annual lime rates are of the order of 250, 100 and $25 \mathrm{~kg} \mathrm{CaO} \mathrm{ha}^{-1}$ on arable land, managed grassland and semi-natural grassland, respectively, and the respective areas of these land uses in England and Wales are 64, 39 and $13 \times 10^{3} \mathrm{~km}^{2}$. If $2 / 56 \mathrm{kmol} \mathrm{OH}^{-}$are produced per $\mathrm{kg} \mathrm{CaO}$ reacting, and $1 \mathrm{kmol} \mathrm{CO}_{2}$ is saved per $\mathrm{kmol} \mathrm{H}^{+}$neutralised by silicate rather than lime, then the total annual avoided emission is close to 1 million $\mathrm{CO}_{2}-\mathrm{C}$.

Data compiled by Renforth et al. $(2009,2011)$ indicate there are many times the required amounts of silicate wastes available from various sources across UK and globally. This includes wastes from igneous rock quarry fines, concrete demolition, slags and fly ash, which amount to several tens of million $\mathrm{t} \mathrm{CO}_{2}-\mathrm{C}$ equivalents.

Therefore, in principle this is a real possibility. The consequences for soil conditions would require further investigation. In particular, the extent to which $\mathrm{SiO}_{2}$ would accumulate in soils over the long term, and the consequences of this for soil conditions; and also the extent of contaminant additions with waste materials. Given that the acidity of the oceans is rising as atmospheric $\mathrm{CO}_{2}$ concentrations rise, the resulting increase in alkalinity might be beneficial. However the ecological consequences are highly uncertain. 
309 Urban soils include any soil of natural or imported origin (e.g. made ground, including engineered fill) 310 or soil that has been modified, for example by the removal of topsoil or its mixture with the subsoil.

311 Urban land accounts for around $9.0 \%$ of land in England, whilst the equivalent percentage for Wales

312 is $4.3 \% \%$ (Morton et al., 2011). It has been suggested that urban soils develop a distinct

313 biogeochemistry from their rural equivalents (Kaye et al. 2006). There is some evidence from

314 England that organic carbon storage may be enhanced in urban soil.

Organic carbon

Analyses of urban soil samples from three locations across the UK showed substantial variations in organic carbon concentrations between centres and no consistent relationships with local, grassland soils (Rawlins et al., 2008). These data, in combination with unpublished data for other centres suggest that the relative importance of the factors which influence soil organic carbon (SOC) concentrations in urban soils may differ from those in rural soils. The wide variation in SOC concentrations in urban topsoil across eight UK urban centres is shown in Table 1. It is notable that median SOC concentrations are particularly large in Leicester (7\%) and Stoke-on-Trent (6.8\%). These values are larger than for both permanent grassland (5.7\%) and ley grassland (3.6\%) in topsoil across England and Wales (data from the Landis database (www.landis.org.uk)). The total quantity of $\mathrm{SOC}$ in urban topsoil (0-15 cm depth) in England is around $8.5 \mathrm{MtC}$. This calculation was based on an estimate of built up areas and garden land area (11 $690 \mathrm{~km}^{2}$; Morton et al., 2011) assuming that (Wood et al., 2006) 50\% has zero carbon due to replacement by a sealed layer. We applied a pedotransfer function to compute bulk density from SOC (Alexander, 1980) using the urban SOC analyses for those data summarised in Table 1.

Further analyses of the SOC data for Coventry and Stoke showed that variations in soil texture cannot account for the large differences in their median SOC concentrations. Application of the RothC model to quantitative data for ten of the sites in Stoke-on-Trent suggested that annual carbon inputs required to maintain SOC concentrations were between 1 and 5.4 tonnes $\mathrm{C} \mathrm{ha}^{-1} \mathrm{yr}^{-1}$; three sites had values $>5$ tonnes $\mathrm{C} \mathrm{ha-1} \mathrm{yr}^{-1}$ which equates to substantial amounts of carbon addition. So either carbon inputs are particularly large at these sites - which is not suggested by local land use - or the processes controlling turnover of organic carbon are different to those found in soils under arable or pasture. If the latter is the case, there are physical, chemical and biological mechanisms which could account for maintenance of larger SOC concentrations. A possible physical mechanism is that urban soils have been more severely compacted - due to construction-related activities - which contributes to the enhanced preservation of SOC as soil microbes cannot mineralize a proportion of soil carbon.

341 Alternatively, the soil microbial population in urban soils may differ from that in equivalent rural soil 342 types leading to changes in carbon turnover and increased SOC concentrations. A potential chemical mechanism is stabilisation of soil organic matter by $\mathrm{Ca}^{2+}$ (Oades, 1988). Soils of urban areas are 
known to be enriched in exchangeable $\mathrm{Ca}^{2+}$ relative to rural soils due to the dispersal of construction wastes (see next section). The other major factor which could account for the variations observed are the frequency and timing of historical soil disturbance at these sampling sites which impact carbon turnover. At present we do not have sufficient information on historic land use change to determine whether this might account for the large observed differences.

In urban areas, architects are increasingly incorporating 'green roofs' into buildings Schrader and Böning (2006) found between 1.8 and 4.6\% carbon in the soils in such roofs in Hannover, depending on age. It is not clear, however, if organic matter was incorporated with a mineral substrate at the start of the experiment and to what extent the observed carbon storage reflects these starting values.

To summarise, it appears there may be a mechanism which is leading to the enhanced storage of organic carbon in urban soil, but to date we do not have sufficient knowledge to explain it. With the data available, we can make some estimates of its potential magnitude for enhancing carbon storage in urban soil. Two urban centres (Stoke-on-Trent and Leicester) have median topsoil organic carbon concentrations of around 7\%, which is between 1 and $2.5 \%$ greater than in the other urban areas. It may be possible to increase SOC concentrations in some urban areas by this quantity, but further research is needed to understand the mechanisms before a soil management strategy or other interventions could be implemented.

Inorganic carbon

The contribution that mineral carbonation - the addition of certain minerals to soils to remove $\mathrm{CO}_{2}$ as carbonates - could make to enhanced carbon storage in soils is discussed above. The essential requirements are the availability of calcium $\left(\mathrm{Ca}^{2+}\right)$ or magnesium $\left(\mathrm{Mg}^{2+}\right)$ cations and a source of base to convert dissolved $\mathrm{CO}_{2}$ to $\mathrm{CO}_{3}{ }^{2-}$. Certain silicate minerals may be suitable for this, and urban soils may be particularly suited because of the local availability of such silicates as wastes from the construction industry. The potential for this has been demonstrated by Renforth et al. (2009) and Washbourne et al. (2012) who measured rates of de novo $\mathrm{CaCO}_{3}$ formation of up to $25 \mathrm{~kg} \mathrm{C} \mathrm{ha}^{-1} \mathrm{yr}^{-1}$ over 10 years in urban brownfield sites receiving demolition waste from concrete buildings. Urban soils are known to be enriched in Ca due to the dispersal of construction wastes, including hydrated cement minerals, the mineral portlandite $\left(\mathrm{Ca}(\mathrm{OH})_{2}\right)$, and, to a lesser extent, gypsum $\left(\mathrm{CaSO}_{4}\right)$ from plasterboard wastes. These minerals are prone to weathering in the soil environment, yielding $\mathrm{Ca}^{2+}$. Using data from the British Geological Survey's geochemistry database for seven urban centres in south and eastern England, we found the concentrations of total Ca were on average $4000 \mathrm{mg} \mathrm{kg}^{-1}$ greater in urban topsoil $(0-15 \mathrm{~cm}$ depth) compared with equivalent, adjacent rural topsoil, with typical enrichments of between 150 and 200\% (Defra, 2010). We restricted our analysis to urban soils in south-east England 
leach dissolved $\mathrm{Ca}^{2+}$ beyond depths of around 1 metre. Based on these data and some simplifying assumptions, we computed the capacity of the soils in these urban areas to sequester $\mathrm{C}$ (based on excess $\mathrm{Ca}$ ) to be $0.5 \mathrm{MtC}$ (megatonnes of carbon).

\section{Enhanced carbon storage in subsoils}

Kleber (2010) and Dungait et al. (2012) suggest that turnover of organic materials in soil is less about what SOM is and more about where it is. Some geological parent materials contain small but significant concentrations of fossil carbon which is incorporated into the soil during its formation. This could be either inorganic, geogenic or organic carbon. An example of the former is the carbon present as carbonate derived from the weathering of chalk parent materials. Organic carbon is also often present in the clay-rich soil parent materials of southern England and also the recalcitrant organic carbon derived from coal-bearing strata. It is not possible to increase the quantities of fossil carbon in soil and so this fossil carbon is outside the scope of our study. However, stabilisation of carbon on the surfaces of minerals derived from weathering of parent material can enhance $C$ storage in the subsoil.

The question we pose here is whether it is possible to increase the quantities of organic carbon stored in the subsoils ( $>25 \mathrm{~cm}$ depth) of England and Wales either through different land management practices (changes in land use or cultivation), or possibly the application of organic amendments to the topsoil. Before we can address this question it is useful to review both the knowledge and knowledge gaps concerning the carbon stored in subsoil of England and Wales and the mechanisms which control it.

Bradley et al. (2005) have estimated that subsoils in England and Wales contain approx. $0.5 \% \mathrm{C}$ by weight (Table 2). On average, soil organic carbon becomes both more recalcitrant and older with increasing depth as soil biota have utilised the simpler organic compounds, leaving behind the more resistant, energy-poor fractions.

Studies have shown that, in topsoils, the dominant factors controlling SOC stabilization include (reviewed by Davidson \& Janssens, 2006) texture, mineralogy, base cation content, soil aggregation, plant litter type and the chemical recalcitrance of soil organic matter, and microbial populations, plus interactions between these factors. This constitutes an extremely complex system. Stewart et al. (2007) demonstrated that certain topsoils may become carbon saturated. The inherent physical and chemical characteristics of the soil may determine the maximum quantity of soil organic matter which can be stabilised (Six et al., 2002). There is strong evidence that iron-oxide content is the dominant factor controlling stabilisation of organic matter in acid forest soils (Mikutta et al., 2006), whilst the quantity of clay and silt are most important in the surface horizons of arable and grassland systems (Hassink \& Whitmore, 1997). 
415 Far less research has been undertaken on subsoil systems. One study showed that when fresh

416 carbon is added to subsoil it has a priming effect which leads to the degradation of previously stable

417 subsoil carbon (Fontaine et al., 2007), though a subsequent study (Salome et al., 2009) observed

418 greater spatial heterogeneity in factors which determine carbon turnover in subsoil compared to

419 topsoil and suggested that controls on carbon turnover may be different between topsoil and subsoil.

420 Observations that the microbial biomass or activity in subsurface soil is more variable than in topsoil

421 suggest that spatial relationships between organic matter and microbial communities may be more

422 significant in the former. This is consistent with observations of distinct flow paths along which

423 younger and less recalcitrant carbon is located, adjacent to the subsoil matrix containing smaller

424 quantities of more recalcitrant carbon (Chabbi et al., 2009). This young carbon is likely to become

425 mineralised in the short or medium-term and may not contribute to long-term carbon storage.

426 There is evidence that the association between mineral surfaces and organic matter in subsoils differs

427 from that in topsoil. Organic matter coatings on subsoil mineral surfaces tend to be thin and patchy

428 whilst those in topsoil samples are thicker and often completely cover mineral particles. So the

429 potential for stabilising organic matter by adsorption to mineral surfaces in subsoil may be

430 substantially less than in topsoil (Wagai et al., 2009). This may in part be explained by the nature of

431 the organic carbon; in subsoil it has undergone more microbial processing by comparison to that in

432 topsoil. The quantity of carbon stored in the subsoil may therefore depend more on its inherent

433 recalcitrance than the mechanisms of its stabilisation on mineral surfaces. Watts et al. (2005)

434 suggested that the action of the microbial biomass was crucial in the binding of organic matter and the

435 formation of soil aggregates and so it is possible that the reduced microbial activity in the subsoils has

436 an effect on carbon stabilisation.

437 Increasing the storage of organic carbon in subsoil (>30 $\mathrm{cm}$ depth) requires: i) a mechanism for its

438 emplacement at depth, and ii) confidence that this carbon will stay in the soil (i.e. be stabilised), and

439 will not be degraded by soil biota or lead to enhanced losses of existing soil carbon. We consider that

440 methods involving direct emplacement of fresh organic carbon into subsoil will not lead to enhanced

441 storage of carbon, and could be counter-productive through disturbance and mineralisation losses of

442 topsoil carbon. An alternative to direct emplacement is to enhance the natural process of migration of

443 carbon from surface to depth; this is dominated by leaching of dissolved organic carbon (DOC).

444 Leaching of DOC is known to be greater under forests than grassland and arable land. Minerals

445 deeper in the soil profile, such as iron oxides, have a large capacity to stabilise this carbon (Mikutta et

446 al., 2006). Plant breeding might also enhance access to these stabilising sites (Kell, 2012)

447 A recent study from California (Sanderman \& Amundson, 2009) demonstrated that DOC movement

448 and retention in a fine-textured (clay-rich) mineral soil contributes $22 \%$ of the annual C inputs below

$44940 \mathrm{~cm}$ in a coniferous forest, whereas only $2 \%$ of the $C$ inputs below $20 \mathrm{~cm}$ in equivalent grassland

450 (prairie) soils were accounted for by this process. The authors suggest that in more coarsely textured

451 soil, the carbon transported to depth may be less effectively stabilised by comparison to clay-rich 
452 lithologies. Another study (Arevalo et al., 2009) which compared the storage of carbon in deeper soil

453 horizons under different land use types also demonstrated that long-term forested sites store more

454 carbon at 20-50 cm depth than recent forest plantation (2-9 years), grassland or crops. The majority

455 of the organic carbon in the subsoil was associated with the finer fractions. Hence, there is evidence

456 that conversion of grassland or arable land use to forest could enhance carbon storage in subsoil

457 where it has a fine texture or large quantities of Fe-oxide phases (Mikutta et al., 2006).

\section{Conclusions}

459 Most means to store carbon in soil suffer from slow build up or restrictions in general use based on

460 climate, soil type or the need to grow food on the land. Those technologies show that promise for

461 widespread, rapid manipulation of the carbon cycle such as (i) the use of polyphenols to complex

462 SOM or inhibit enzymes that decompose it, (ii) enhancing storage in topsoil based on mechanisms of

463 physical protection that currently operate in the subsoil, or (iii) mineral carbonation, all require

464 research before they could be used or their potential deployment in practice be assessed. Increased

465 use of improved grasses where possible could increase carbon storage now; breeding might provide

466 additional perennial crops or varieties in the future that divert carbon to the subsoil. Interventions on

467 urban soils are necessarily restricted to a small percentage of the land area. 


\section{References}

Abberton, M.T.,,MacDuff, J.H.,,Marshall, A.H. \& Humphreys, M.W. 2007. The genetic improvement of forage grasses and legumes to reduce greenhouse gas emissions. ftp://ftp.fao.org/docrep/fao/010/ai779e/ai779e00.pdf. pp 17.

Aerts, R.J., Barry, T.N. \& McNabb, W.C. 1999. Polyphenols and agriculture: beneficial effects of proanthocyanidins in forages. Agriculture Ecosystems and Environment, 75, 1-12.

Andrews, J.E., Burgess, D., Cave, R.R., Coombes, E.G., Jickells, T.D., Parkes, D.J. \& Turner, R.K. 2006. Biogeochemical value of managed realignment, Humber estuary, UK. Science of the Total Environment, 371,19-30.

Andrews, J.A. \& Schlesinger, W.H. 2001. Soil $\mathrm{CO}_{2}$ dynamics, acidification, and chemical weathering in a temperate forest with experimental $\mathrm{CO}_{2}$ enrichment. Global Biogeochemical Cycles, 15, 149162.

Anon (2011) The natural choice: securing the value of nature. TSO pp 75.

Anon (2011) UK National Ecosystem, Assessment, Technical report, UNEP-WCMC pp 1466

Arevalo, C.B.M., Bhatti, J.S., Chang, S.X. \& Sidders, D. 2009. Ecosystem carbon stocks and distribution under different land-uses in north central Alberta, Canada. Forest Ecology and Management, 257, 1776-1785.

Billett, M.F., Charman, D.J, Clark, J.M., Evans, C.D., Evans, M.G., Ostle, N.J., Worrall, F., Burden, A., Dinsmore, K.J., Jones, T., McNamara, N.P., Parry, L., Rowson, J.G. \& Rose, R. 2010. Carbon balance of UK peatlands: current state of knowledge and future research challenges. Climate Research, 45, 13-29.

Blagodatsky, S., Blagodatskaya, E., Yuyukina, T. \& Kuzyakov, Y. 2010. Model of apparent and real priming effects: Linking microbial activity with soil organic matter decomposition. Soil Biology \& Biochemistry, 42, 1275-1283.

Bolin, B., Sukmar, R., Cias, P., Cramer, W., Jarvis, P., Kehshgi, H., Nobre, C., Semenov, S. \& Steffen, W. 2000. Global perspective. Pages 23-51 in Land use, land-use change, and forestry, a special report of the IPCC. Eds R.T. Watson, I.R. Noble, B. Bolin, N.H. Ravindrannath, D.J. Verardo \& D.J. Dokken. Cambridge University Press, Cambridge .

Benoit, R.E. \& Starkey, R.L. 1968a. Effect of purified plant tannin on decomposition of some organic compounds and plant materials Soil Science, 105, 153-158.

Benoit, R.E. \& Starkey, R.L.1968b. Enzyme inactivation as a factor in the inhibition of decomposition of organic matter by tannins. Soil Science, 105, 203-208.

de Boer W., Folman, L.B., Summerbell, R.C. \& Boddy, L. 2005. Living in a fungal world: impact of fungi on soil bacterial niche development. Fems Microbiology Reviews, 29, 795-811.

Bradley, R.I., Milne, R., Bell, J., Lilly, A., Jordan, C. \& Higgins, A. 2005. A soil carbon and land use database for the United Kingdom. Soil Use and Management, 21, 363-369.

Carney, K.M., Hungate, B.A., Drake, B.G. \& Megonigal, J.P. 2007. Altered soil microbial community at elevated $\mathrm{CO}_{2}$ leads to loss of soil carbon. Proceedings of the National Academy of Sciences, 104, 490-495. 
Chabbi, A., Kögel-Knabner, I. \& Rumpel, C. 2009. Stabilised carbon in subsoil horizons is located in spatially distinct parts of the soil profile. Soil Biology and Biochemistry, 41, 256-261.

Conant, R.T., Easter, M., Paustian, K., Swan, A. \& Williams, S. 2007. Impacts of periodic tillage on soil C stocks: A synthesis. Soil \& Tillage Research, 95, 1-10

Davidson, E.A. \& Janssens, I.A. 2006. Temperature sensitivity of soil carbon decomposition and feedbacks to climate change. Nature 440, 376-386.

Defra. 2006. Land by agricultural and other uses: 2005. e-Digest of Environmental Statistics, Environment in your pocket, Sustainable Development Indicators in your Pocket. Defra, London.

Defra. 2008. British Survey of Fertiliser Practice. Fertiliser Use on Farm Crops for Crop Year 2007. Defra, London.

Defra 2009. Safeguarding our soils - A strategy for England pp48

Defra, 2010. To evaluate the potential of technologies for increasing carbon storage in soil to mitigate climate change. SP1605 A - sub-project A. Defra, London.

Defra. 2012. Grip blocking and methane emissions. Final report of project SP1202. Defra, Lodnon.

Dungait, J.A.J., Hopkins, D.W., Gregory, A.S. and Whitmore, A.P. (2012) Soil organic matter turnover is governed by accessibility not recalcitrance. Global Change Biology. 18, 1781-1796. doi: 10.1111/j.1365-2486.2012.02665.x

Fontaine, S., Barot, S., Barre, P., Bdioui, N., Mary, B. \& Rumpel C. 2007. Stability of organic carbon in deep soil layers controlled by fresh carbon supply. Nature, 450, 277-210.

Freeman, C., Ostle, N. \& Kang, H. 2001. An enzymic 'latch' on a global carbon store Nature, 409, 149.

Glasstone, S., Laidler, K.J. \& Eyring, H. 1941. The Theory of rate processes, McGraw-Hill, New York.

Glover, J.D., Reganold, J.P., Bell, L.W., Borevitz, J., Brummer, E.C., Buckler, E.S., Cox, C.M., Cox, T.S., Crews, T.E., Culman, S.W., DeHaan, L.R., Eriksson, D., Gil,I B.S., Holland, J., Hu, F., Hulke, B.S., Ibrahim. A.M.H., Jackson, W., Jones, S.S., Murray, S.C., Paterson, A.H., Ploschuk, E., Sacks, E.J., Snapp, S., Tao,, D.D. van Tassel. L Wade, L.J., Wyse, D.L. \& Xu Y. 2010. Increased food and ecosystem security via perennial grains. Science, 328, 1638-1639

Guo, L.B. \& Gifford, R.M. 2002. Soil carbon stocks and land use change: a meta analysis. Global Change Biology, 8, 345-360.

Guo, Z.L., Cai, C.F., Li, Z.X., Wang, T.W. \& Zheng, M.J.. 2009. Crop residue effect on crop performance, soil $\mathrm{N}_{2} \mathrm{O}$ and $\mathrm{CO}_{2}$ emissions in alley cropping systems in subtropical China. Agroforestry Systems, 76, 67-80.

Hartmann, J. \& Kempe, S. 2008. What is the maximum potential for $\mathrm{CO}_{2}$ sequestration by "stimulated" weathering on the global scale? Naturwissenschaften, 95, 1159-1164.

Hassink, J. \& Whitmore, A.P. 1997. A model of the physical protection of organic matter in soils. Soil Science Society of America, Journal, 61, 131-139.

Jones, D.L., Nguyen, C. \& Finlay, R.D. 2009. Carbon flow in the rhizosphere: carbon trading at the soil-root interface. Plant and Soil, 321, 5-33.

Jose, S. 2009. Agroforestry for ecosystem services and environmental benefits: an overview. Agroforestry Systems, 76, 1-10. 
Kaye, J.P., Groffman, P.M., Grimm, N.B., Baker, L. M. \& Pouyat, R.V. 2006. A distinct urban biogeochemistry? Trends in Ecology and Evolution, 21, 192-199.

Kell, D.B. (2012) Large-scale sequestration of atmospheric carbon via plant roots in natural and agricultural ecosystems: why and how. Philos Trans R Soc Lond B Biol Sci. 367,1589-97. doi: 10.1098/rstb.2011.0244.

Kirk, G.J.D., Bellamy, P.B. \& Lark, R.M. 2010. Changes in soil pH across England and Wales in response to decreased acid deposition. Global Change Biology, 16, 3111-3119.

Kuzyakov, Y. 2010. Priming effects: Interactions between living and dead organic matter. Soil Biology \& Biochemistry, 42, 1363-1371.

Manning, D.A.C. \& Renforth, P. 2013. Passive sequestration of atmospheric $\mathrm{CO}_{2}$ through coupled plant-mineral reactions in urban soils. Environmental Science \& Technology, 47, 135-141.

Mikutta, R., Kleber, M., Torn, M. S. \& Jahn, R. 2006. Stabilization of soil organic matter: Association with minerals or chemical recalcitrance? Biogeochemistry, 77, 25-56.

Montagnini, F. \& Nair, P.K.R. 2004. Carbon sequestration: An underexploited environmental benefit of agroforestry systems. Agroforestry Systems, 61, 281-295.

Morton, D., Rowland, C., Wood, C. Meek, L., Marston, C., Smith, G., Wadsworth, R., Simpson, I.C. 2011. Final Report for LCM2007 - the new UK land cover map. Countryside Survey Technical Report No 11/07 NERC/Centre for Ecology \& Hydrology 112pp.

Moulton, K.L., West, J. \& Berner, R.A. 2000. Solute flux and mineral mass balance approaches to the quantification of plant effects on silicate weathering. American Journal of Science, 300, 539-570.

Nair, P.K.R., Kumar, B.M. \& Nair, V.D. 2009a. Agroforestry as a strategy for carbon sequestration. Journal of Plant Nutrition and Soil Science, 172, 10-23.

Nair, P.K.R., Nair, V.D., Kumar, B.M. \& Haile, S.G. 2009b. Soil carbon sequestration in tropical agroforestry systems: a feasibility appraisal. Environmental Science \& Policy, 12, 1099-1111.

Nye, P.H. \& Ameloko, A.Y, 1987. Predicting the rate of dissolution of lime in soil. Journal of Soil Science,38, 641-644.

Oades, J.M. 1988. The retention of organic matter in soils. Biogeochemistry, 5, 35-70.

Paterson, E., Midwood, A.J. \& Millard, P. (2009) Tansley Review. Through the eye of the needle: a review of isotope approaches to quantify microbial processes mediating soil carbon balance. New Phytologist, 184, 19-33.

Powlson, D.S., Bhogal, A., Chambers, B.J., Macdonald, A.J., Coleman, K., Goulding, K.W.T. \& Whitmore, A.P. 2012. The potential to increase soil carbon stocks through reduced tillage or organic additions - an England and Wales case study. Agriculture, Ecosystems and Environment 146, 23-33.

Powlson, D.S., Whitmore, A.P. \& Goulding, K.W.T. 2011. Soil carbon sequestration to mitigate climate change - a critical re-examination to identify the true and the false. European Journal of Soil Science, 62, 42-55.

Quinkenstein, A., Wollecke, J., Bohm, C., Grunewald, H., Freese, D., Schneider, B.U. \& Huttl, R.F. 2009. Ecological benefits of the alley cropping agroforestry system in sensitive regions of Europe. Environmental Science \& Policy, 12, 1112-1121. 
Rawlins, B.G., Vane, C.H., Kim, A.W., Tye, A.M., Kemp, S. \& Bellamy, P.H. 2008. Methods for estimating types of soil organic carbon and their application to surveys of UK urban areas. Soil Use \& Management, 24, 47-59.

Renforth, P., Manning, D.A.C. \& Lopez-Capel, E. 2009. Carbonate precipitation in artificial soils as a sink for atmospheric carbon dioxide. Applied Geochemistry, 24, 1757-1764.

Renforth, P., Washbourne, C.-L., Taylder, J. \& Manning, D.A.C. 2011. Silicate production and availability for mineral carbonation. Environmental Science \& Technology, 45, 2035-2041.

Rimmer, D.L. 2006. Free radicals, antioxidants, and soil organic matter recalcitrance. European Journal of Soil Science, 57, 91-94.

Rimmer, D. L., McKenna, B. A., Vaughan, S. M. Menzies, N. W. (2013) Antioxidant capacity and rate of decomposition of organic amendments in a Vertisol European Journal of Soil Science 64,

104-109 DOI 10.1111/ejss.12001

Rimmer, D.L. \& Smith, A.M. 2009. Antioxidants in soil organic matter and in associated plant materials. European Journal of Soil Science, 60, 170-175.

Royal Society. 2009a. Reaping the benefits: Science and the sustainable intensification of global agriculture. RS Policy document 11/09. The Royal Society, London.

Royal Society. 2009b. Geoengineering the climate. Science, governance and uncertainty. RS Policy document 10/09. The Royal Society, London.

Russell, E.W. 1973. Soil conditions and plant growth. Longman, London.

Salome, C., Naoise, N., Valerie, P., Thomas, Z.L. \& Claire C. 2009. Carbon dynamics in topsoil and in subsoil may be controlled by different regulatory mechanisms. Global Change Biology, 16, 416426.

Sanderman, J. \& Amundson, R. 2009. A comparative study of dissolved organic carbon transport and stabilization in California forest and grassland soils. Biogeochemistry, 92, 41-59.

Schuiling, R.D. \& Krijgsman, P. 2006. Enhanced weathering: An effective and cheap tool to sequester $\mathrm{CO}_{2}$. Climate Change, 74, 349-354.

Shackley S \& Sohi S (2009) Final Report to Defra project SP0576: An assessment of the benefits and issues associated with the application of biochar to soil pp 132

Sinasbaugh RL 2010 Phenol oxidase, peroxidise and organic matter dynamics of soil. Soil Biology and Biochemistry 42, 391-404.

Six, J., Conant, R.T., Paul, E.A. \& Paustian K. 2002. Stabilization mechanisms of soil organic matter: Implications for C-saturation of soils. Plant and Soil, 241, 155-176.

Skinner, R.H., Sanderson, M.A., Tracy, B.F. \& Dell, C.J. 2006. Above and belowground productivity and soil carbon dynamics of pasture mixtures. Agronomy Journal, 98, 320-326.

Smith, P., Powlson, D.S., Smith, J.U., Falloon, P. \& Coleman, K. 2000. Meeting Europe's climate change commitments: quantitative estimates of the potential for carbon mitigation by agriculture. Global Change Biology, 6, 525-539.

Stewart, C.E., Paustian, K., Conant, R.T., Plante, A.F., \& Six, J. 2007. Soil carbon saturation: concept, evidence and evaluation. Biogeochemistry, 86, 19-31. 
Stockmann, U., Adams, M.A., Crawford, J.W., Field, D.J, Henakaarchchi, N., Jenkins, M., Minasny, B., McBratney, A.B., de Remy de Courcelles, V., Singh, K., Wheeler, I., Abbott, L., Angers, D.A., Baldock, J., Bird, M., Brookes, P.C., Chenu, C., Jastrow, J.D. Lal, R., Lehmann, J., Donnell, A.G., Parton, W.J., Whitehead, D., Zimmermann, M. (2013) The knowns, known unknowns and unknowns of sequestration of soil organic carbon, Agriculture, Ecosystems \& Environment. 164, 80-99, 10.1016/j.agee.2012.10.001.

Tisdall, J.M. \& Oades, J.M. 1982. Organic matter and water-stable aggregates in soil. Journal of Soil Science, 33,141-163.

Toberman, H., Freeman, C., Evans, C., Fenner, N. \& Artz, R.R.E. 2008. Summer drought decreases soil fungal diversity and associated phenol oxidase activity in upland Calluna heathland soil. FEMS Microbiology Ecology 66, 426-436.

Verchot, L.V., Brienza, S., de Oliveira, V.C., Mutegi, J.K., Cattanio, J.H. \& Davidson, E.A. 2008. Fluxes of $\mathrm{CH}_{4}, \mathrm{CO}_{2}, \mathrm{NO}$, and $\mathrm{N}_{2} \mathrm{O}$ in an improved fallow agroforestry system in eastern Amazonia. Agriculture Ecosystems \& Environment, 126,113-121.

Wagai, R., Mayer, L.M. \& Kitayama, K. 2009. Extent and nature of organic coverage of soil mineral surfaces assessed by a gas sorption approach. Geoderma, 149, 152-160.

Washbourne, C.-L., Renforth, P. \& Manning, D.A.C. 2012. Investigating carbonate formation in urban soils as a method for capture and storage of atmospheric carbon. Science of the Total Environment, 431, 166-175.

Watts, C.W., Whalley, W.R., Brookes, P.C., Devonshire, B.J. \& Whitmore, A.P. 2005. Biological and physical processes that mediate micro-aggregation of clays. Soil Science, 170, 573-583.

Webb, J., Loveland, P.J., Chambers, B.J., Mitchell, R. and Garwood, T. 2001. The impact of modern farming practices on soil fertility and quality in England and Wales. Journal of Agricultural Science, Cambridge, 137, 127-138.

Wood, G., Braganza, S., Brewer, T., Kamporaki, M,, Harris, J. et al. 2006. Monitoring urban sealing from space. Technical report of GIFTSS project BNSC/ITT/54, Defra code SP0541. http://randd.defra.gov.uk/Default.aspx?Menu=Menu\&Module=More\&Location=None\&Completed=0 \&Project|D=12897

Wutzler, T. \& Reichstein, M. 2008. Colimitation of decomposition by substrate and decomposers - a comparison of model formulations. Biogeosciences, 5, 749-759.

Zibilske, L.M. \& Bradford, J.M. 2006. Oxygen effects on carbon, polyphenols and nitrogen mineralisation potential in soil. Soil Science Society of America Journal, 71 133-139. 
Table 1 Median soil organic $C$ contents of urban top soils ( $0-15 \mathrm{~cm}$ depth) from eight urban centres in the UK

\begin{tabular}{lccc|}
\hline Urban centre & $\begin{array}{c}\text { Sample } \\
\text { counts }(\mathrm{n})\end{array}$ & $\begin{array}{c}\text { Median OC* } \\
\left(\mathrm{g} \mathrm{kg}^{-1}\right)\end{array}$ & $\begin{array}{c}\text { Median OC* } \\
(\%)\end{array}$ \\
\hline Glasgow & 1382 & 52 & 5.2 \\
Stoke-on-Trent & 747 & 68 & 6.8 \\
Coventry & 396 & 34 & 3.4 \\
Derby & 276 & 43 & 4.3 \\
Manchester & 301 & 49 & 4.9 \\
Leicester & 309 & 70 & 7.0 \\
Belfast & 1198 & 41 & 4.1 \\
London** & 6468 & 43 & 4.2 \\
\hline
\end{tabular}

* estimated from loss on ignition analysis - may include a component of recalcitrant (black) carbon

$\star * ?$

Source of data?

Q why both $\mathrm{g} / \mathrm{kg}$ and $\%$, Also shouldn't $43 \mathrm{~g} / \mathrm{kg}$ be $4.3 \%$ ? 
Table 2 Average organic $C$ contents of subsoils at two depth ranges in different land uses across England and Wales

\begin{tabular}{ccccc}
\hline Soil depth range $(\mathrm{cm})$ & \multicolumn{4}{c}{ Organic C content $\left(\mathrm{g} \mathrm{kg}^{-1}\right)$} \\
\cline { 2 - 5 } & Arable & Ley grass & $\begin{array}{c}\text { Permanent } \\
\text { grass }\end{array}$ & Other \\
\hline $25-50$ & 13.0 & 13.6 & 15.7 & 18.5 \\
$50-100$ & 3.6 & 4.0 & 4.4 & 4.3 \\
\hline
\end{tabular}

